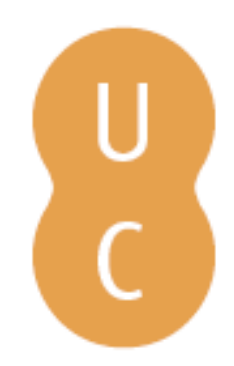

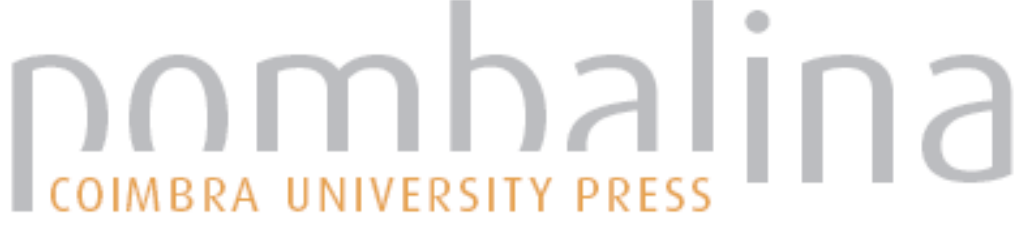

Thematic division and tactical analysis of the UAS application supporting forest fire management
Autor(es):
Restas, Agoston
Publicado por: Imprensa da Universidade de Coimbra
URL
persistente:
URI:http://hdl.handle.net/10316.2/34189
DOI:
DOI:http://dx.doi.org/10.14195/978-989-26-0884-6_172
Accessed : $\quad$ 26-Apr-2023 01:29:52

A navegação consulta e descarregamento dos títulos inseridos nas Bibliotecas Digitais UC Digitalis, UC Pombalina e UC Impactum, pressupõem a aceitação plena e sem reservas dos Termos e Condições de Uso destas Bibliotecas Digitais, disponíveis em https://digitalis.uc.pt/pt-pt/termos.

Conforme exposto nos referidos Termos e Condições de Uso, o descarregamento de títulos de acesso restrito requer uma licença válida de autorização devendo o utilizador aceder ao(s) documento(s) a partir de um endereço de IP da instituição detentora da supramencionada licença.

Ao utilizador é apenas permitido o descarregamento para uso pessoal, pelo que o emprego do(s) título(s) descarregado(s) para outro fim, designadamente comercial, carece de autorização do respetivo autor ou editor da obra.

Na medida em que todas as obras da UC Digitalis se encontram protegidas pelo Código do Direito de Autor e Direitos Conexos e demais legislação aplicável, toda a cópia, parcial ou total, deste documento, nos casos em que é legalmente admitida, deverá conter ou fazer-se acompanhar por este aviso.

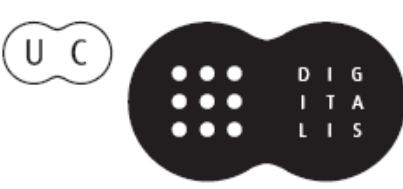




\section{ADVANCES IN}

Forest Fire

\section{RESEARCH}

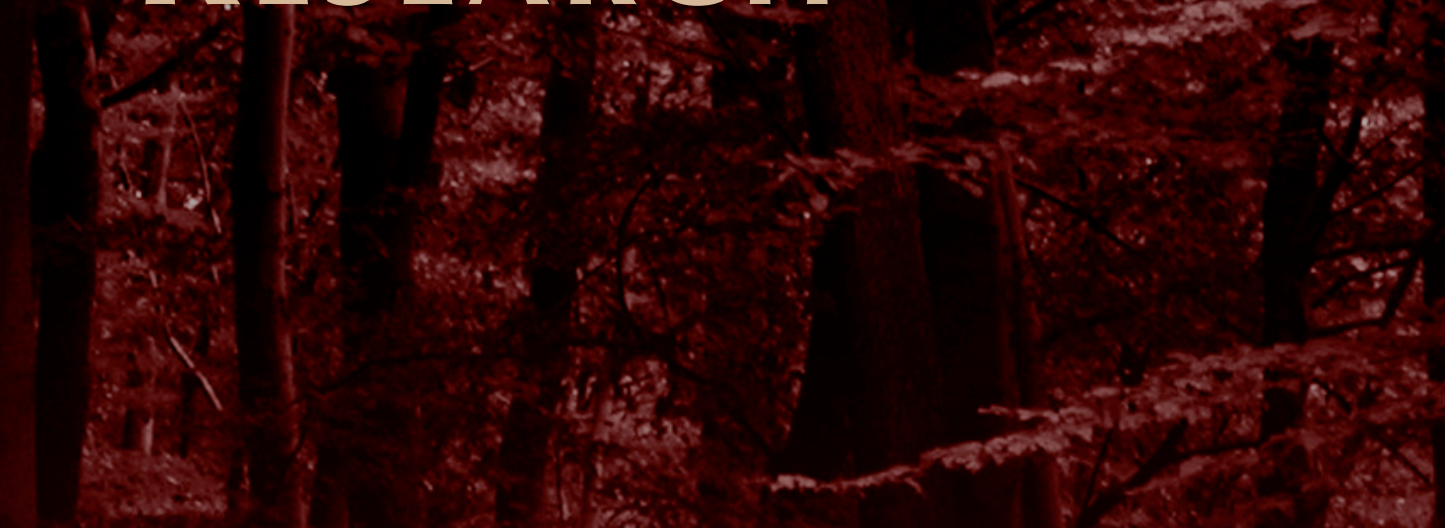

\section{DOMINGOS XAVIER VIEGAS}

\section{EDITOR}




\title{
Thematic division and tactical analysis of the UAS application supporting forest fire management
}

\author{
Agoston Restas \\ National University of Public Service, Budapest, Hungary, Restas.Agoston@uni-nke.hu
}

\begin{abstract}
Introduction: This paper describes many initiatives and shows also practical examples which have happened using Unmanned Aerial Systems to support fire managers in different ways. Since the operation of manned aircraft at forest fires is usually expensive, in many cases managers miss the aerial activity even for reconnaissance however that would be required for the effective intervention. Today more and more experts say Unmanned Aerial Systems can give real alternatives for aerial reconnaissance even if this application is far from manager's mentality yet. Methods: Author used thematic division of Unmanned Aerial Systems applications; it is based on two key elements, one of them is the time flow of fighting forest fires, the other is its tactical requirements. Research used mainly author's own experiences in this field, accompanied by function analysis, practical experiments, economic analysis and also expert estimation. Results and discussion: Logically Unmanned Aerial Systems can be used before fire for hot spot detection, before starting the intervention for fire reconnaissance, during the intervention for intervention monitoring and after suppression for post fire monitoring. The method of prescribed fire can also be in the focus of Unmanned Aerial Systems use as a special application for fire prevention.
\end{abstract}

Keywords: Unmanned Aerial Systems (UAS), tactical analysis, forest fire management, fire detection, fire monitoring, prescribed fire

\section{Introduction}

The operation of manned aircraft at forest fires is usually expensive, therefore in many cases managers miss the aerial activity even for reconnaissance or supporting decision making, even if that would be required for the effective intervention. Today's experiences say Unmanned Aerial Systems ${ }^{1}$ (UAS) can give real alternatives of manned aircraft's operation not just for aerial reconnaissance but even other activities. This paper describes many initiatives and shows also practical examples which have happened using UAS to support fire managers in different ways.

UAS activities regarding forest fire is not new. We can reel off activities using UAS to fight against forest fire in the United States (Ambrosia and Hinkley, 2009), in Croatia (Hucaljuk, 2004; Restas, 2013), in Spain (Ollero, 2004; Pastor, 2008). In Hungary the Szendro Fire Department carried out many activities helping fire management using UAS (Restas, 2004).

This paper gives an approach for thematic division of using UAS at forest fires; it is based on the tactical differences. Logically UAS can be used before fire for hot spot detection, during the intervention helping fire management and after suppression for post fire monitoring. The method of prescribed fire can be also in the focus of UAS use as a special application for fire prevention. (Restas, 2011)

The paper uses the chronological flow of fighting forest fire for thematic divisions, although the last part of this paper, the UAS generated prescribed fire can be disputed; it could have been also the first part. As a latest development of this application author found it as the latest place for the best.

1 There are other abreviations like UAV (Unmanned Aerial Vehicle) or RPAS (Remotely Piloted Aircraft Systems) meaning the similar technology as UAS. „Drone” is also used for this technology. 


\section{Aerial patrol for hot spot detection}

Aerial patrol with manned aircraft is a commonly used procedure for detecting hot spot. Many countries such as Australia, Canada, France, Russia, Spain, and United States regularly use this procedure while others such as Germany and Poland used to apply it but today not.

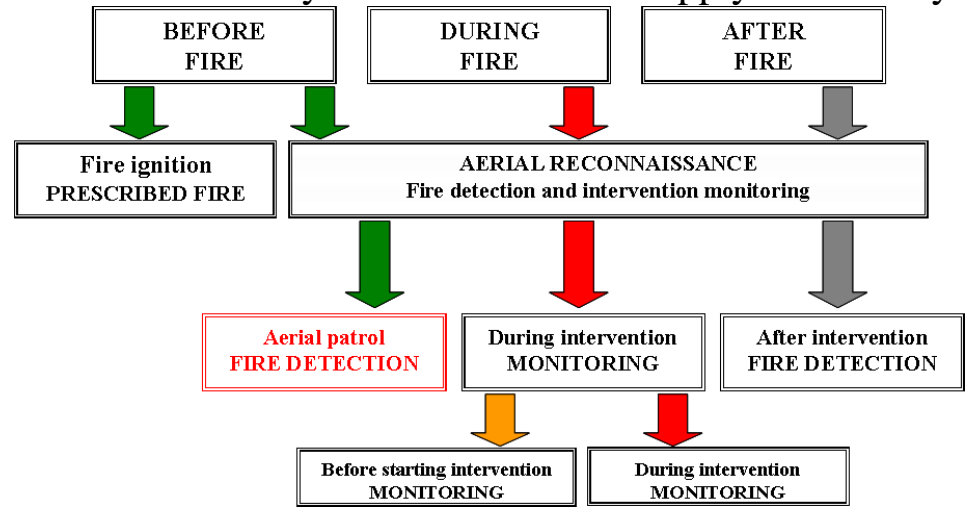

Figure 1. Aerial patrol for hot spot detection in the structure of thematic division of UAS use

Detecting hot spots by aerials earlier than reporting it by civilians obviously helps fire managers limit the damages fires cause. Unfortunately, the main reason why this method is not always used is the huge costs of aerials. If the procedure made by UAS is cheaper than the traditional one (manned aircraft), it means that the option of UAS use is the better solution. Naturally this case assumes the similar professional efficiency of different methods.

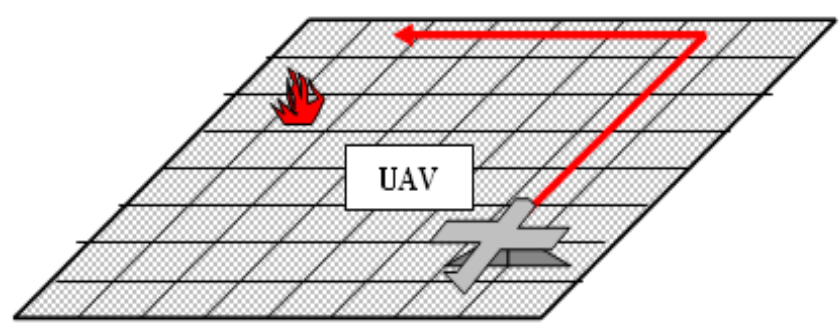

Figure 2. Planning UAS mission for hot spot detection

During this task UAS makes a patrol following the pre-programmed flight path and based on the real time video supply the staff in the control station can detect and check any hot spots. In case of real danger staff reports it to the fire service.
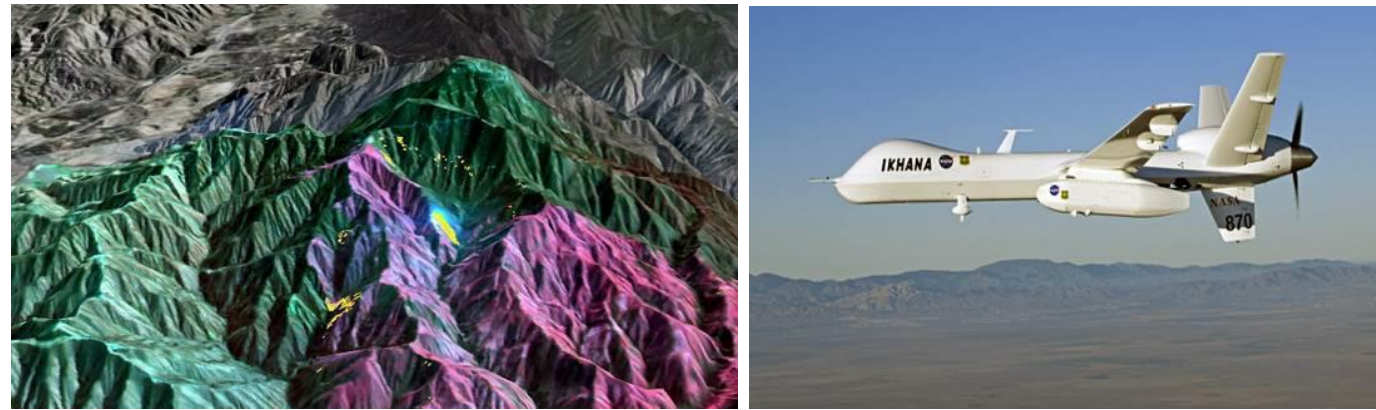

Figure 3. UAS mission in the United States. Ikhana strategic UAS 

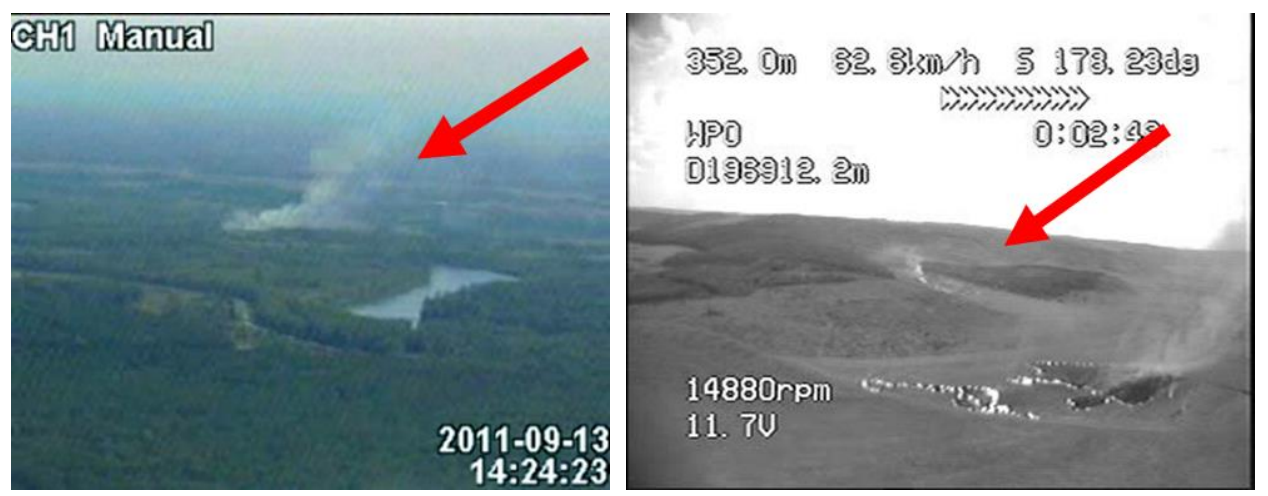

Figure 4. UAS based hot spot detections: in Croatia (2011) and the first one in Hungary (2004)

No doubt, aerial patrol by UAS can detect hot spots very quickly and it is able to give the first fire report to fire brigades. It can reduce the time of first attack but study says that based on economic calculations, this application can be effective just under special conditions such as at extremely high Fire Weather Index and at geographically high articulated area. Detailed criteria must be developed in the future for optimizing the effectiveness of UAS applications.

For effective hot spot detection different type of UAS can be used. Depending on the area staff responsible for both strategic and operational UAS can be effective tool for the early hot spot detection. In the United States the high altitude long endurance (HALE) Ikhana was used for both early detection and intervention monitoring. In Croatia and Hungary tactical UAS were also used for hot spot detection.

\section{Aerial reconnaissance before starting intervention}

When starting intervention the main problem is the lack of objective information regarding the affected area, fire intensity, etc. (Bleszity, 1989). Operational used UAS could help in this case; below just a few minutes it can be ready for launch and 2-3 minutes later it transmits the real time pictures about the fire and their circumstances.

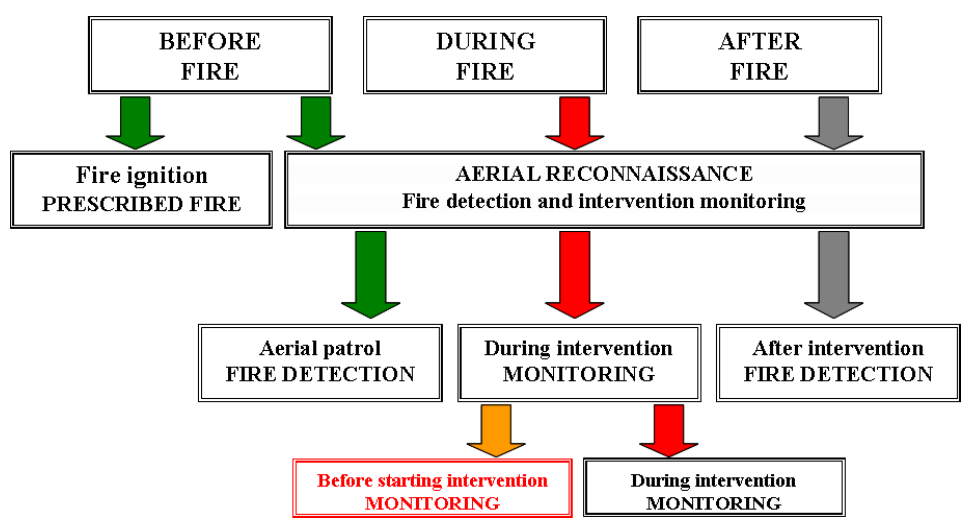

Figure 5. Aerial reconnaissance before starting intervention in the structure of thematic division of UAS use

For aerial patrol aimed at hot spot detection the reasonable type of UAS belongs to the category of high altitude, long endurance or medium altitude long endurance (HALE, MALE) band. In this case a special UAS service can also be used effectively. In case of aerial reconnaissance before starting 
intervention the situation is totally different. Fire managers require some basic information about fires immediately and for this task a highly qualified UAS service is not applicable.

In case of aerial reconnaissance the quick access to the information is much more important than the quality (e.g. resolution of the video, photos) of that. Therefore the simple but immediately ready for start UAS is required for this type of task. Capability of this type of UAS is limited. Fire manager needs objective information about the fire characteristic, fire intensity, speed of spreading fire, smoke emission, wind direction, etc. but very quickly. For this task a hand launch, by electric engine powered UAS is considered the best solution.
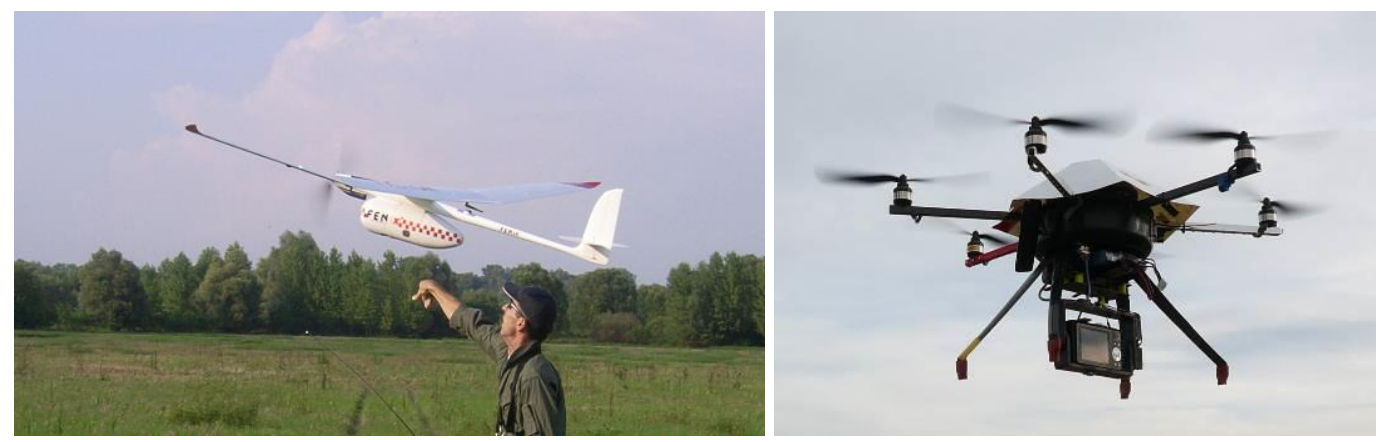

Figure 6. Launch of fix wing UAS (Fenix) for fire reconnaissance before starting intervention. Rotary wings UAS (Bee) hovering at forest fire. Source: 6DOF (Croatia) and R-Fire Ltd. (Hungary)

The simple criterion for economic effectiveness is that all costs of UAS use must remain below the value of the forest saved by this process.
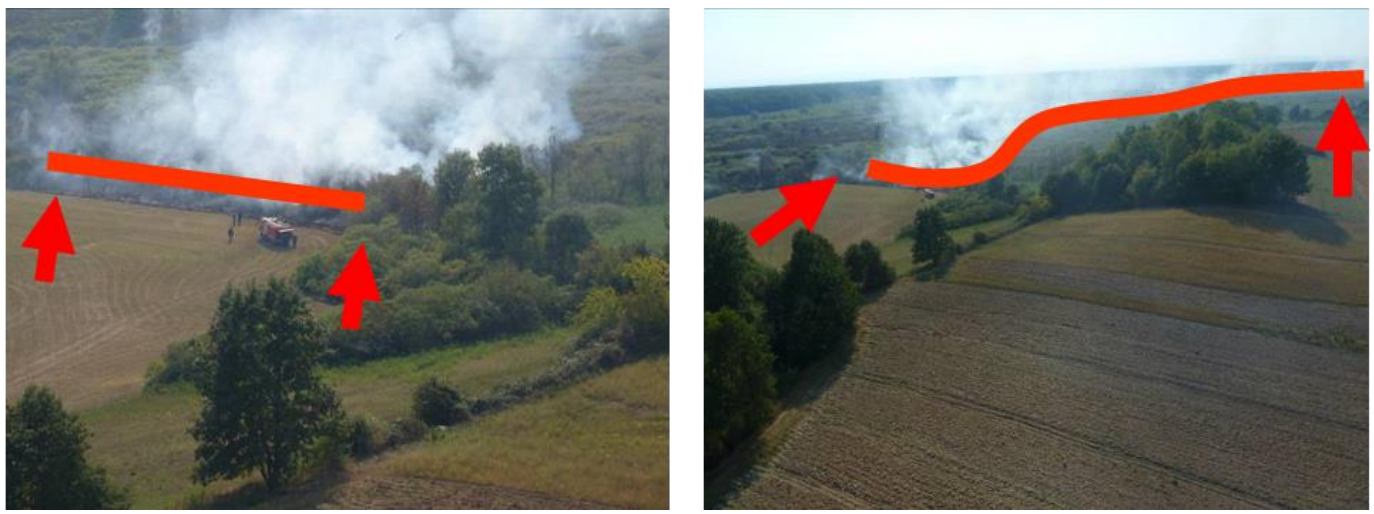

Figure 7. Differences between fire fronts can be seen face to face or from the air after arriving. UAS supported intervention in Hungary (DRAVIS II, 2011)

\section{Aerial reconnaissance during intervention}

During intervention, where aerial reconnaissance is required but manned aircraft is above price, UAS could give also a cost effective solution. If the commander of fire-fighting operations is at the scene, he is too close to the fire to be able to manage it along with its environment. Quite literally, he cannot see the forest for the trees! As the extinction of forest fires is a protracted process in time, and since during that time the fire will continue to spread, the ability to manage a fire together with its environment is an indispensable precondition for the efficient extinguishing of a fire.

Manned aircraft is used on several occasions to assist with the reconnaissance of forest fires. However, these fires cover very large areas and putting them out takes several days, and the fire-fighting action 
is managed at higher levels of the organisation, usually at executive staff level. These experiences indicate that air reconnaissance is effective.

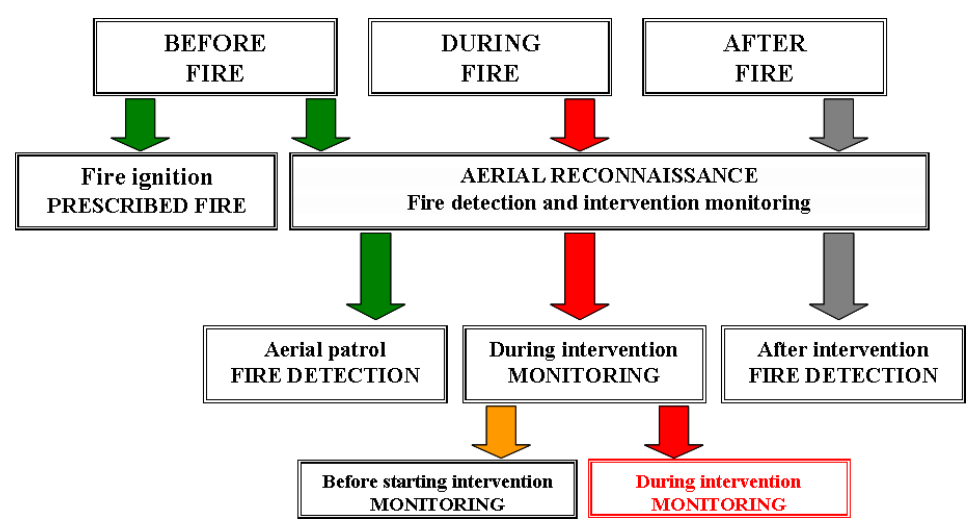

Figure 8. Aerial monitoring during intervention in the structure of thematic division of UAS use

During intervention the UAS use can be very effective because obtaining an overview of several hundred or even thousand hectares of forest allows intervention measures to be co-ordinated. Without air reconnaissance, co-ordination of measures can only be based on the information circulating between the commanders of individual units at various locations. But the assessment of the scope of their individual situations by commanders located at various sites may be completely subjective and not made in relation to the other sites. Air reconnaissance helps to eliminate subjectivity in such judgements and to rank the individual sites in relation to the others.
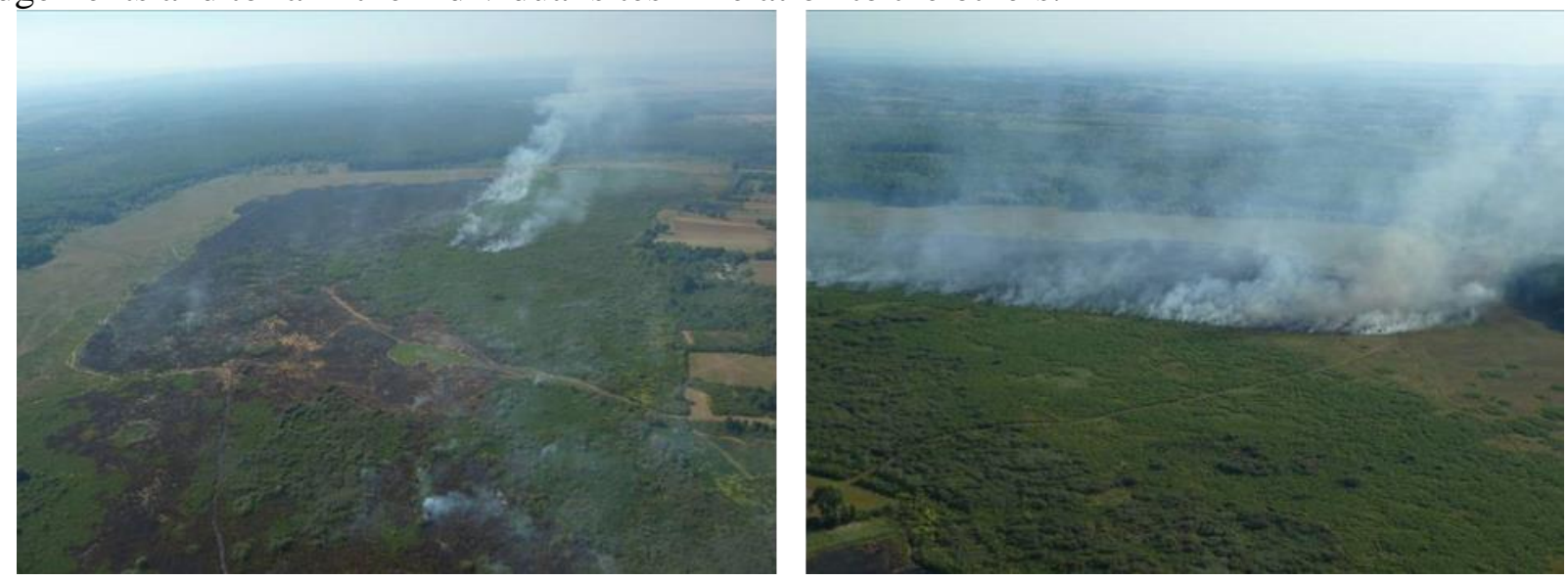

Figure 9. Typical fire forms: spot fire and linear fire spread. Photos made by UAS in Croatia (2011)

At huge fires using manned aircraft for bombing water or just to support the reconnaissance with information is a normal procedure. On the other hand, small fires don't require aerial support; these are managed by traditional equipment. Between these extremes, logically, there is a sector, where fire size is larger than management could suppress successfully just with traditional equipment, but not large enough to ask manned aircraft for help. In this case the manned aircraft is economically, obviously, not effective, but a solution such as UAS - which is cheaper than the use of manned aircraft - can already be.

If the UAS based aerial reconnaissance satisfies the minimum criteria of the professional requirements of the effective reconnaissance, it means that this solution can be even economically effective. 


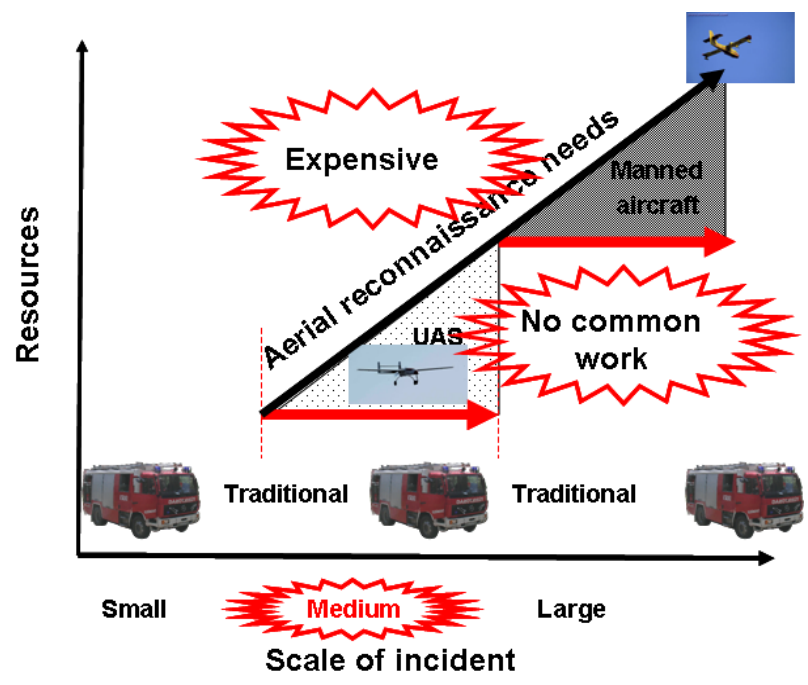

Figure 10. Efficiency of UAS application depends on fire size

We can demonstrate the effectiveness of UAS based aerial reconnaissance also by the damage - time function. This kind of applications is not just reducing the damages caused by the fire but even reducing the time of the intervention. Shorter intervention is reducing also the risk posed to citizens caused by the lack of fire fighters who are ready for alarm in case of accident, house fire, etc. Unfortunately this kind of risk is usually assessed much lower than the reality requires.
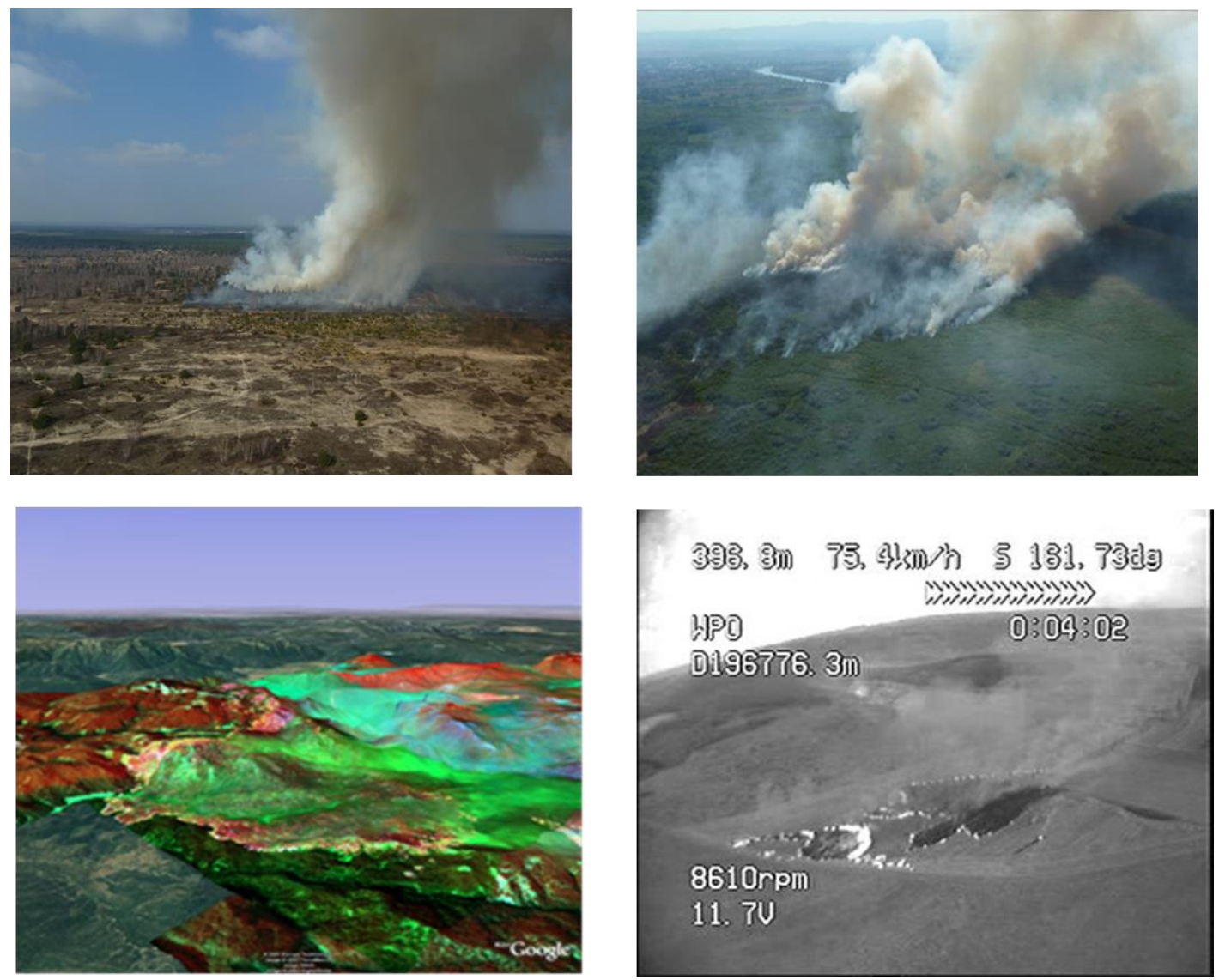

Figure 11. Intervention supported by UAS: forest fires in coloured (Bee, Germany, 2010, and Phoenix, Croatia, 2011), artificial coloured (Ikhana, US, 2007) and black and white photos (Hungary, 2004) 


\section{Post-fire monitoring}

After suppressions, many times, area surveillance is required to prevent starting fire again by remained cinder. UAS equipped with IR camera can detect the critical points easily and with a small team can manage hot spots while let fire fighters leave the area.

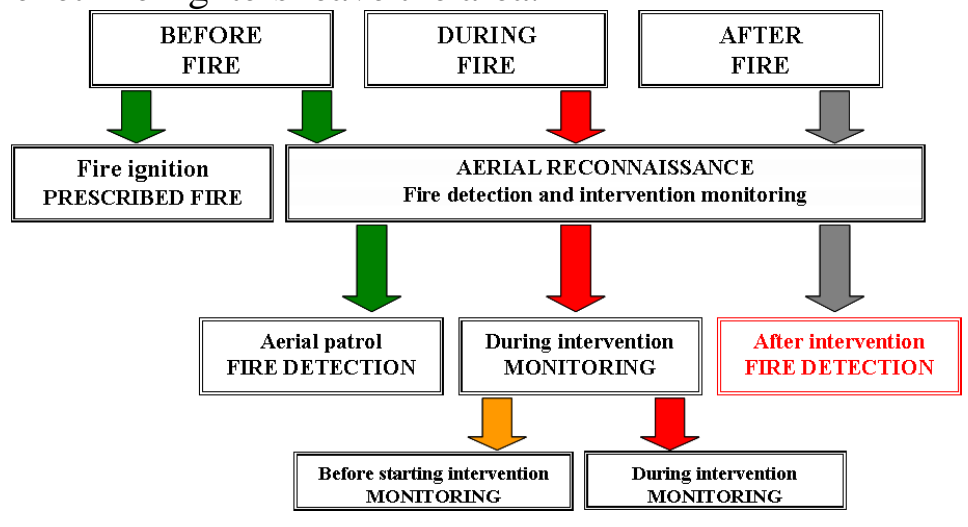

Figure 12. Post-fire monitoring in the structure of thematic division of UAS use

Burnt area monitoring besides the tactically advantages gives also other options. Since many cases UAS use is optimal when it is in the hand of fire service, the post fire monitoring is ideal for training recruit. After the intervention, there is no stress regarding success, no pressure from media or residents. But post fire monitoring is a real task while its environment means a reality. It means hot spots, remained cinder what also requires responsible management.
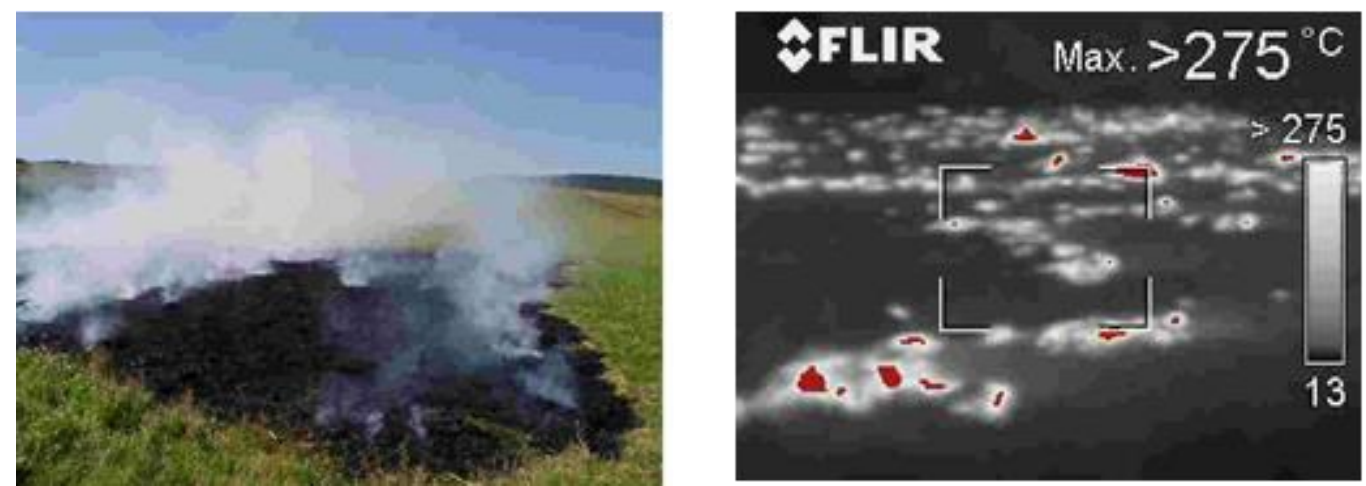

Figure 13. Thermo cam is installed on UAS board and able to detect the remained cinder

Planning the post-fire monitoring UAS must fly around the extinguished fire front instead of monitoring the whole area (hot spot detection). For this task a simple but with IR equipped UAS is required.
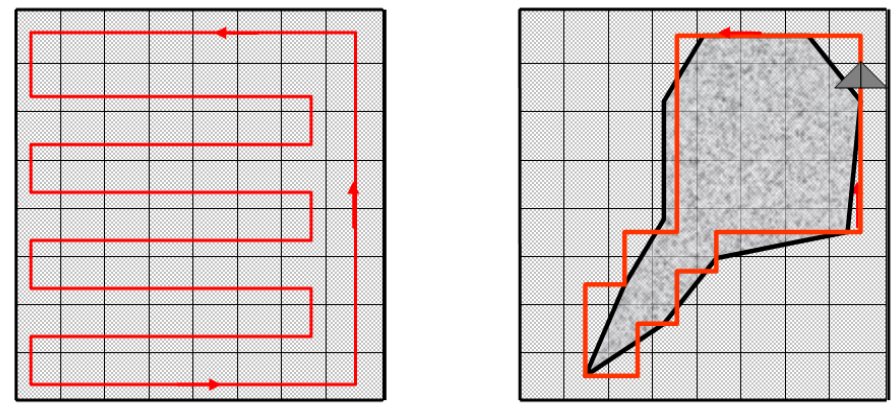

Figure 14. Differences between planning UAS mission for early fire detection and remained cinder detection 


\section{Prescribed fire - made by UAS}

There are other initiatives such as making prescribed fires with using medium size UAS. The special equipment filled with fire eggs or pastilles weighs less than the payload capacity of UAS. It means UAS can provide also this task, giving more possibilities for managers using prescribed fires method with limited costs.

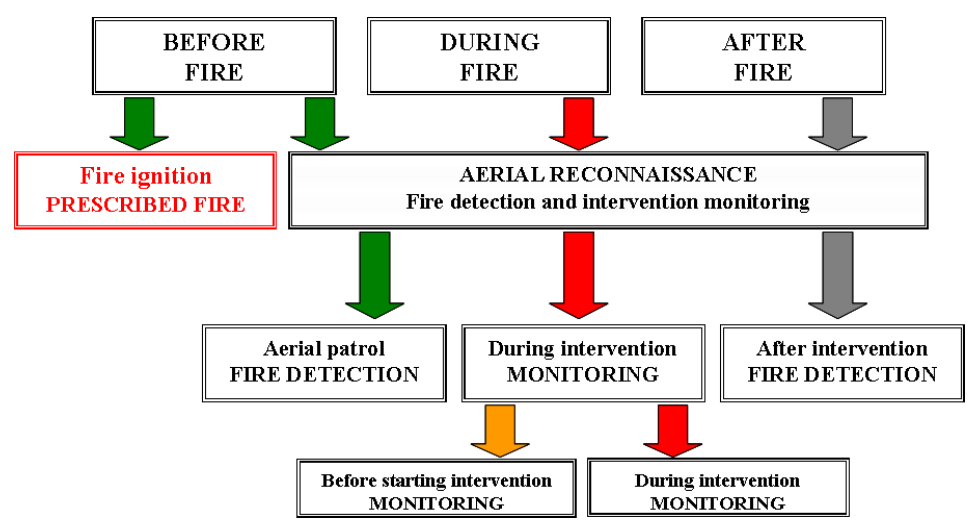

Figure 15. UAS generated prescribed fire in the structure of thematic division of UAS use

No doubt, prescribed fire is a very effective management tool for avoiding the serious fires in critical seasons. In this process fire managers burn areas with controlled fire reducing the fuel load of the territories. Less fuel load means less fire intensity and damage. There are different ways from hand tools (drip torch) till aerial means making this process.

For the sake of better efficiency today managers can use special equipment for this task such as fire eggs and pastilles. These equipment weighs about $20 \mathrm{~kg}$. This method means that a light helicopter carries these $20 \mathrm{~kg}$ weight machines for dropping the eggs or pastilles. Since both fix wing and rotary wings UAS are able to carry this machine, we can supply this task also with UAS.

Professionally there is no difference in effectiveness between manned aircraft or UAS. There are other tactical advantages of using UAS for generating controlled fire. UAS can fly not just in day mission but also at night widening the term when control fire can be made. It means the possibilities of UAS generated fire is more than just giving an alternative solution.
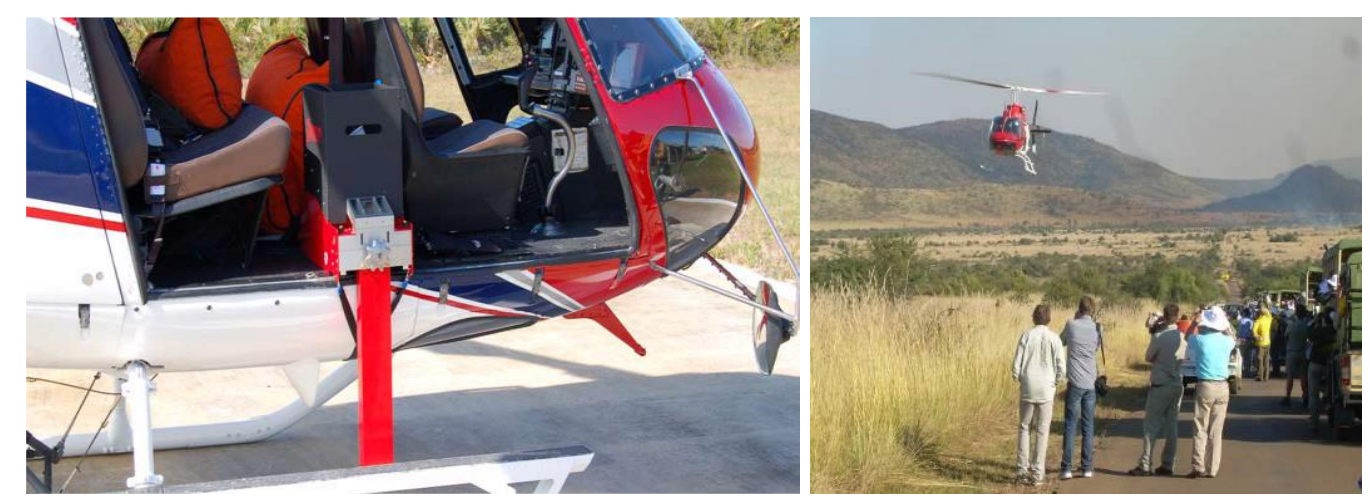

Figure 16. Example for the special equipment generating prescribed fire and a real application

As usual we can demonstrate the effectiveness of UAS generated control fire also by the damage time function. Since the prescribed fire reduced the fuel load in case of not intended fire the fire intensity will remain at low level. Low level fire intensity means reduced fire spread, more time for intervention and limited severity. 


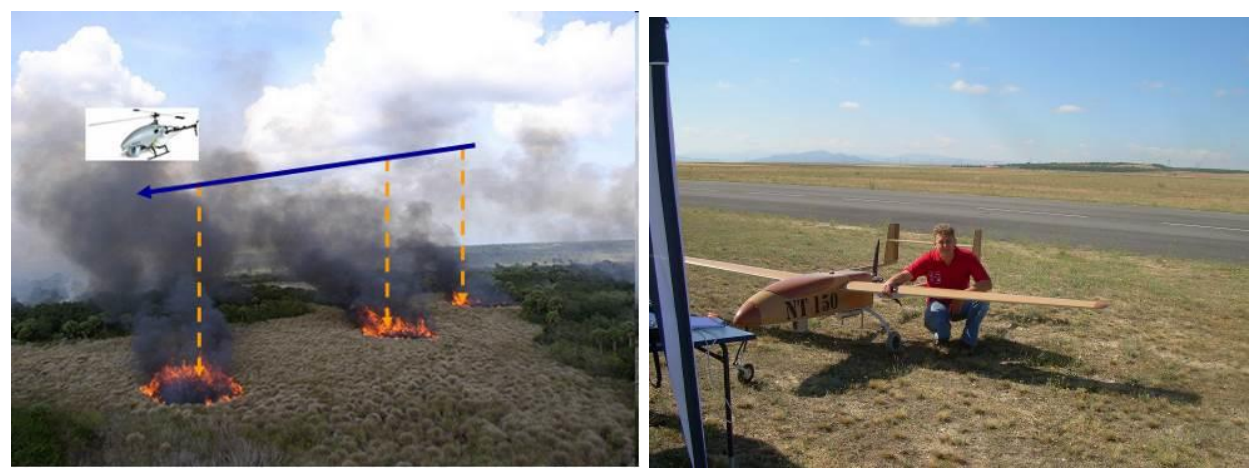

Figure 17. Method of UAS generated prescribed fire and an example of UAS ready for doing it

\section{Results}

Based on the above examples UAS can be a very effective tool in the hand of fire managers. After launch the UAS can supply real time data continuously, therefore within in the first few minutes it can provide effective support for the decisions of the commander. One such element of decision support is that even before the UAS returns, it will be possible to establish the extent of the burning area and to request the assistance of further units. This will save a significant amount of time.

Another example of decision support: if commanders are able to manage the entire area in a complex way, it may be the case that protecting the area where the fire is currently most intense is the most important task. It is possible that our forces need to be concentrated in a location other than that furnished by the initial assessment.

While firefighting is in progress, the fire continues to spread in the areas where no countermeasures are taken, and indeed it may meet natural obstacles or barriers. A river, a wider road or glade may stop the fire as a natural barrier, so beginning fire-fighting measures at a distance of 100 or 200 metres from such a natural barrier can only be considered efficient if we have plenty of resources.

On the other hand, it is also possible that in a direction which currently has low parameters for spread and is thus assessed as lower priority, there lies a much more valuable area, such as a highly protected plant community, a habitat of protected animals, or perhaps an area of vegetation with higher parameters for spread.

The above examples show that the most efficient intervention is not necessarily the same as intervention at the point where the fire is the most intense. In order to make the best decision, the area of the fire must be managed in a complex manner, together with its environment.

The tactical UAS, which has proven effective, can be made available to even the smallest fire brigades. Traditional reconnaissance no longer provides information of a quality and quantity sufficient for today's applications. Increasing the efficiency of reconnaissance will result in increasingly efficient interventional measures. This will increase the area of forests saved while reducing the areas destroyed. The workload of fire-fighters may be reduced; in many instances there may be no need to mount a response at all. The elimination of unnecessary responses will reduce the level of risk to citizens, resulting in a higher level of fire safety.

\section{References}

Ambrosia, V. and Hinkley, E.: UAS Applications: Science, Applied Science, and Civil Applications "UAS For Earth Remote Sensing Workshop" International Symposium on Remote Sensing of Environment (ISRSE), Stresa, Italy, 3 May 2009 
Bleszity J. and Zelenak, M.: A tuzoltas taktikaja (Tactics of firefighting) Ed.: BM Konyvkiado, Budapest, 1989

Hucaljuk M. 2004. "Remote Sensing of Wild Fires by an Ultra-light Unmanned Aerial Vehicle", 24th EARSeL Symposium New Strategies for European Remote Sensing, Dubrovnik, Croatia, 25-27 May 2004

Ollero A., Hommel G., Gancet J., Gutierrez L.G., Viegas X.D., Forssén P.E., González M.A.: "COMETS: A multiple heterogeneous UAV system". IEEE International Workshop on Safety, Security and Rescue Robotics SSRR 2004, Bonn, Germany, May 24-26, 2004.

Pastor, E. (et al.): Project SKY-EYE, Applying UAVs to Forest Fire Fighter, Support and Monitoring; Department of Computer Architecture; Technical University of Catalonia, Spain, 2008

Restas, A.: Robot Reconnaissance Aircraft. UAVnet 9th Meeting, Amszterdam, Netherlands, 2004

Restas, A.: UAV Applications From Aerial Patrol to Prescribed Fires; Wildfire2011 The $5^{\text {th }}$ International Wildland Fire Conference, Sun City, South Africa, 9-13 May 2011

Restas, A.: Cost Effective Solution of Aerial Means for Supporting Large Scale Firefighter's Incidents, Advances Fire and Safety Engineering, Zilina, Slovakia, 2013 